\title{
Book Review: 'Ctrl-Alt-Del', A Review of Language Put to Work by Enda Brophy
}

\author{
Arianna Bove \\ Queen Mary, University of London, London UK, a.bove@qmul.ac.uk
}

Abstract: Arianna Bove reviews Enda Brophy's Language Put to Work: The Making of the Global Call Centre Workforce (2018). Palgrave Macmillan.

Keywords: Call Centre, Communication, Immaterial Labour, Workers' Inquiry

"I don't know why she's always complaining about work. All she does is sit down all day talking on the phone". So Zi' Giovanni disparaged over his granddaughter's exhaustion, as he bent his eighty-four-year-old back to harvest his pride and joy, juicy tomatoes growing from the soil of the Italian village he lived most of his life away from. Zi' Giovanni and his brothers Davide and Michele, no money or educational qualification to their name, fled to Canada as almost chattel labour to work on railway construction. Their remittances afforded the progeny literacy and education: the key to nonmanual labour. My cousin was not alone in migrating to the North to work in a call centre. The best at my high school even ventured to Dublin, the European capital of transnational telework. Swathes of educated youths fleeing the physical toil of their ancestors, trading the pains of hard backbreaking graft for carpal tunnel syndrome and stress.

In Language Put to Work: The Making of the Global Call Centre Workforce, Enda Brophy paints a striking picture of our generation, underpaid, overworked, betrayed, wasted. The book is published by Palgrave in the series Dynamics of Virtual Work curated by Ursula Huws and Rosalind Gill, solid sociologists at the forefront of research on labour in the digital age. Despite the seemingly circumscribed remit of the inquiry, great ambition is shown in its charting of the dynamics of a changing global workforce in a moving global industry: seasickness warnings apply.

\section{What Work?}

The kind of work investigated is captured under different labels: info-service work, immaterial labour, knowledge work, communicative production. It is not until the last chapter that Brophy explains his preference for a definition of the work going on in call centres as "immaterial labour". This might come as a surprise. Since its first dissemination in the late 1990s, the expression has been criticised by Marxists and was eventually disowned even by its main proponent Maurizio Lazzarato, ${ }^{1}$ understandably so: although immaterial referred to the product of the work (information, communication, affect, symbols, images, ideas, brands, relations), the expression suggested that there was something immaterial about the activity too. Brophy's recovery of this expression is counter-current but not untoward:2 "immaterial labour" originally sought to describe

\footnotetext{
${ }^{1}$ See Lazzarato's seminal essay on Immaterial Labour, available here: http://www.generationonline.org/c/fcimmateriallabour3.htm

2 More in the spirit of the classic Andrè Gorz's The Immaterial: Knowledge, Value and Capital.
} 
the expansion of relations of service and greater integration of markets, factories and supply chains in Post-Fordism, as well as counterbalance the naive portrayal of "knowledge work" by management-friendly scholars as a semi-professional and emancipated form of labour, and this is at the core of Brophy's project too.

Starting in the 1990s, when with the relocation of manufacturing away from countries of origin, the service industry was heralded as the mop-up of an overspill of labour that went hand in hand with the spread of higher education, graduates could take on office jobs and keep their hands clean from oil or soil or coal. Brophy's investigation shatters all dreams about it. Toil becomes mental more than physical, and in this, it is equally soul-destroying.

\section{Measure Your Words}

Antonio Gramsci said of scientific management: "Taylor expresses the real purpose of American society - replacing in the worker the old psycho-physical nexus of qualified professional work, which demanded active participation, intelligence, fantasy, and initiative, with automatic and mechanical attitudes. This is not a new thing, it is rather the most recent, the most intense, the most brutal phase of a long process that began with industrialism itself" (Gramsci 1971, 598). ${ }^{3}$

Now high-tech surveillance tools in the hands of performance management make for nasty work environments; as Barbara Garson predicted at the end of the 1980s "a combination of twentieth-century technology and nineteenth century scientific management will turn the office of the future into the factory of the past" (Garson, quoted in Brophy, 37). ${ }^{4}$

Brophy's inquiry shows how this brutal phase unfolds in the third industrial revolution, but loyal to the tradition of Autonomous Marxism and workers' inquiry, he never characterises workers as passive, reactive subjects, let alone victims. The staff turnover is high: not many stick it out. The job has no prospects, it is precarious and lowly paid, ripe for refusal and sabotage. Time-theft, double wrap, slamming, ending calls as soon as they become 'unprofitable', denial of service attacks, ${ }^{5}$ rebooting computers to take three-minute breaks; Brophy presents a terrific "compendium of the call centre workforce's art of resistance" (17), widespread experiences, often not publicised, falling under the radar of trade union politics of recognition.

Brophy is Foucauldian here in two important respects. First, because he refuses to analyse the inner rationality of power - the manner in which management science develops techniques to measure and increase productivity, as if that was what really mattered. Instead, he uses resistance as the "chemical catalyst" because it brings to light power relations (43). Second, because he believes that the Taylorist measures and standardisation of communication are ultimately doomed to fail. He underlines how, beyond adding to the pain of work, these also thwart workers' identification with the goals of the employers, hindering the potential interiorisation of command. If anything, in call centres the self is deconstructed and left dissembled: identities dissolved and masked. With no organisational identification, there is no danger of workaholism. The

${ }^{3}$ It continues: "This phase will itself be superseded by the creation of a new psycho-physical nexus, both different from its predecessors and superior. As a consequence, a part of the old working class will be eliminated from the world of work, and perhaps from the world." Americanismo e Fordismo was written in 1929-32 but first published in 1949.

4 The citation stems from Barbara Garson's 1988 work The Electronic Sweatshop: How Computers Are Transforming the Office of the Future into the Factory of the Past.

${ }^{5}$ Notoriously by Scottish Widow workers in the United Kingdom who pro-actively helped customers recover their forgotten pension benefits. 
psychic drudgery of call centre work produces disengaged subjects. Digital Taylorism forces the separation of conception and execution at the level of language and resistance becomes a question of survival.

\section{Travel to Work}

The consequences of this become more evident as soon as Brophy turns his attention to "organised" resistance. As efforts to unionise are recounted, the reader gradually comes to appreciate the meaning of the subtitle, how different this global workforce "in the making" is from that of the nineteenth and twentieth century. The case studies take us from Canada to Ireland, Australia, to New Zealand, India and China, back to Europe in Germany, Italy and the United Kingdom. In a game of cat and mouse, with unexpected twists, drawbacks, leaps across borders and sudden role reversals, in Brophy's narrative the cat is organised labour, global capital the fleeing mouse. The pattern of organised resistance is one repeated across borders: prolonged, hard-fought struggles followed by basic concessions from employers are a prelude to companies' relocation to more docile labour markets. ${ }^{6}$

Low-cost call-centre offices pop up as fast as they are taken down around the globe. This mobility has allowed for the emergence of a specialised global industry: "sellers of industrialised consumer interaction". Virtual migration, outsourcing and offshoring facilitated the creation of a global call-centre industry that segregates front-line infoservice workers from parent companies. A "new breed of multinationals" grows, clumsily moving across borders in search of the path of least resistance. "By $2006,20 \%$ of the 100 largest non-financial transnational corporations listed by UNCTAD was a company providing services, compared to only 7\% in 1997" (139). Offshoring often retraces colonial geographies whilst hearkening the techniques of dissimulation; workers are trained in "location masking", simulated accents, scripted utterances: various forms of language disembodiment and de-subjectivation.

Caminar preguntando, the author has travelled and asked questions. The tone throughout the book is soft and understated, sweeping statements are kept to a minimum, the narrative is punctuated with disclaimers: these cases might be rare, the book is not presenting events as a tendency, struggles are not generalisable, the stories presented might be anecdotal. He is careful not to turn the perspectivism of resistance into one-sided wishful thinking. And this standpoint is a clearer lens through which to look into the reality of this work. The purpose? To unmake it.

Universities churn out graduates in ever-larger quantities, training them in communication, high on the list of "employability" skills. Call centre work is the graduate job par excellence, and upon entering it youngsters are untaught to be smart, improvise, establish rapport, take initiative, put their skills to work, and are instead trained in automatic communication, depersonalisation of speech - the de-subjectification of language. It is no wonder that exhaustion is rife and turnover high. My grandfather Davide used to say: "Get an education: no one can take that away from you". And he was right: no one can. But those tomatoes were tasty.

${ }^{6}$ Brophy reports that in 2001, the company Orange, soon to be merged with T-Mobile to form EE (Everything Everywhere), informed its Darlington staff in Britain that they could keep their jobs if they moved to the Philippines, with details of a rice allowance they could claim in Manila as part of the transfer. 


\section{References}

Gorz, André. 2010. The Immaterial: Knowledge, Value and Capital. Translated by Chris Turner. London and New York: Seagull Books.

Gramsci, Antonio. 1971. Selections from the Prison Notebooks. Edited and translated by Quentin Hoare and Geoffrey Nowell Smith. London: Lawrence and Wishart. Accessed February 2018. http://abahlali.org/files/gramsci.pdf

Lazzarato, Maurizio. 1996. Immaterial Labour. Translated by Paul Colilli and Ed Emery. In Radical Thought in Italy. A Potential Politics, edited by Michael Hardt and Paolo Virno. Minnesota: University of Minnesota Press. Accessed February 2018. http://www.generation-online.org/c/fcimmateriallabour3.htm

\section{About the Author}

\section{Arianna Bove}

Arianna Bove is Lecturer in Politics and Ethics at Queen Mary, University of London. 